\title{
PENGARUH PENDAPATAN ASLI DAERAH, DANA ALOKASI UMUM, DANA ALOKASI KHUSUS, DAN RASIO PEMBIAYAAN UTANG TERHADAP TRANSPARANSI INFORMASI KEUANGAN DAERAH VIA WEBSITE
}

\author{
Intan Nurbaiti Fawziah', Fefri Indra Arza ${ }^{2}$ \\ ${ }^{1}$ Alumni Jurusan Akuntansi Fakultas Ekonomi Universitas Negeri Padang \\ ${ }^{2}$ Jurusan Akuntansi Fakultas Ekonomi Universitas Negeri Padang \\ *Korespondensi: nurbaitifawziah@gmail.com
}

\begin{abstract}
The objective of this study determine the effect of Regional Orginal Revenue, General Allocation Funds, Special Allocation Funds, and Debt Financial Ratios to Transparency of Regional Financial Information via Website which is divided to two proxies namely Availability and Accessibility of Regional Financial Information via Website. Sample in this study is the district or city goverment in Indonesia in 2017. Sampling was conducted using a purposive sampling method. The type of data used is secondary data. Independent variable data were obtained from the BPK Audit Reports in 2017 and data obtained from the local goverment website. As for the dependent variable data obtained fro each official site of the local goverment. Data analysis technique used in this study are of two models, namely logistic regression analysis and multiple regression analysis. Result of the test show that Regional Original Revenue has no significant effect on the availability of regional financial via website, Regional Original Revenue has a significant effect on the accessibility of regional financial information via website. General Allocation Funds, Special Allocation Funds and Debt Financial Ratio also do not have a significant effect to availability and accessibility of regional financial information via website.
\end{abstract}

Keywords : Website; Debt Financial Ratios; General Allocation Funds; Regional Original Revenue; Special Allocation Funds; Transparency, .

How to cite (APA $6^{\text {th }}$ style)

Fawziah, I. N \& Arza, F. I. (2020). Pengaruh Pendapatan Asli Daerah, Dana Alokasi Umum, Dana Alokasi Khusus, Dan Rasio Pembiayaan Utang Terhadap Transparansi Informasi Keuangan Daerah Via Website. Jurnal Eksplorasi Akuntansi. 2(1), Seri B, 2200-2213.

\section{PENDAHULUAN}

Peraturan Pemerintah No. 71 tahun 2010 tentang Standar Akuntansi Pemerintahan mengungkapkan laporan keuangan disusun untuk menyediakan informasi yang relevan mengenai posisi keuangan dan seluruh transaksi yang dilakukan oleh entitas pelaporan selama satu periode pelaporan dan setiap entitas wajib melaporkan secara transparan. Transparansi adalah 
keterbukaan informasi kepada masyarakat karena adanya hak untuk mengetahui seluruh pertanggungjawaban pemerintah dalam mengelola sumber daya yang dipercaya serta merupakan taatnya pemda pada undang-undang.

Transparansi dibagi menjadi dua yaitu ketersediaan dan aksesibilitas informasi keuangan daerah via website. Ketersediaan informasi keuangan daerah via website adalah tersedianya komponen laporan keuangan berdasarkan PP No. 71 tahun 2010. Aksesibilitas informasi keuangan daerah via website adalah kemudahan masyarakat untuk mencari dan melihat informasi keuangan yang disediakan pada website pemda. Undang-undang No. 14 tahun 2018 tentang Keterbukaan Informasi Publik membuktikan bahwa transparansi telah berkembang di Indonesia menyatakan bahwa Badan Publik wajib menyediakan informasi publik yang akurat, benar dan tidak menyesatkan. Badan publik harus membangun dan mengembangkan sistem informasi dan dokumentasi untuk mengelola informasi publik secara baik dan efisien sehingga dapat diakses dengan mudah. Informasi keuangan dapat diakses dengan mudah melalui internet.

Informasi yang dibutuhkan oleh institusi publik atas pelaporan keuangan pemerintah daerah adalah informasi kepatuhan terhadap aturan, informasi kinerja, informasi kondisi keuangan dan informasi perencanaan dan penganggaran. Tidak hanya itu, laporan keuangan pemerintah daerah juga harus berkualitas yakni relevan, andal, dapat dibandingkan, serta dapat di pahami oleh penggunanya. Pengungkapan informasi dalam laporan keuangan memiliki dampak ekonomis dan subtansial dalam pengambilan keputusan. Dalam pelaporan keuangan pemerintah daerah, baik pihak eksekutif maupun legislatif sama-sama berkepentingan untuk memastikan bahwa laporan keuangan pemerintah daerah telah memberikan penjelasan yang memadai mengenai kepatuhan terhadap aturan, informasi kinerja, informasi kondisi keuangan, serta informasi perencanaan dan penganggaran (Novia et.al, 2015)

Styles dan Tennyson (2007) mengatakan bahwa nternet adalah media yang mudah dijangkau oleh masyarakat dan sarana yang paling cost effective bagi pemerintah untuk mempublikasikan informasi keuangannya dalam bentuk pelaporan online. Website merupakan salah satu penerapan e-goverment karena dengan website mempermudah masyarakat dalam mengetahui potensi daerah dan informasi tentang jalannya pemerintahan termasuk informasi keuangan. Meskipun tujuannya mulia, penyediaan akses dan pengungkapan informasi pengelolaan anggaran dan keuangan daerah kepada publik melalui website resmi pemda masih menjadi problem pada sebagian besar pemda di Indonesia (termasuk Sumatera Barat).

Hal tersebut terlihat dari penelitian Agustin (2014) menemukan bahwa belum seluruh pemkab/pemkot di propinsi Sumatera Barat memanfaatkan menu transparansi pengelolaan anggaran (TPA) dalam website resmi pemerinta daerah untuk mempublikasikan secara lengkap dan konsisten jenis dokumen-dokumen terkait dengan penggunaan anggaran. Meskipun sebagian besar website Kabupaten di Sumatera Barat telah terdapat menu khusus/link bernama TPA (transparansi pengelolaan anggaran) untuk mendownload informasi atau dokumen keuangan dan kinerja tetapi menu khusus dan link tersebut terkadang kosong, tidak memuat secara lengkap, dan tidak dipublikasikan secara konsisten setiap tahunnya. Selain itu, riset Agustin dan Arza (2019) menemukan anomali antara akuntabilitas dan transparansi publik terkait dengan manajemen pengelolaan keuangan daerah. Akuntabilitas publik telah meningkat dalam 7 tahun terakhir (2012-2019), dimana seluruh pemerintah kabupaten/kota di propinsi Sumatera Barat mempublikasikan pada website resmi maupun media massa setiap opini WTP dari BPK atas LKPD. Namun perilaku serupa tidak terjadi dalam konteks transparansi publik, dimana hampir setengah dari 19 pemerintah kabupaten/kota di propinsi Sumatera Barat yang bersedia 
mengungkapkan secara terbatas dokumen-dokumen terkait pengelolaan anggaran daerah (hanya 5-7 dokumen dari total 12 dokumen).

Tujuan penelitian adalah untuk mengetahui pengaruh Pendapatan Asli Daerah, Dana Alokasi Umum, Dana Alokasi Khusus dan Rasio Pembiayaan Utang terhadap Transparansi Informasi Keuangan Daerah via Website.

\section{REVIU LITERATUR DAN PENGEMBANGAN HIPOTESIS Teori Agensi}

Jhensen dan Meckling (1976) mengatakan dalam teori keagenan terdapat kesepakatan dari dua pihak yaitu hubungan yang muncul ketika satu pihak (prinsipal) memberikan kewenangan dan tanggung jawab kepada pihak lain (agen) untuk melakukan pengambilan keputusan. Hubungan keagenan tersebut terjadi pada pemerintahan dan masyarkat. Masyarakat memberikan tugas kepada pemerintah dalam melakukan tugas pemerintah untuk kesejahteraan masyarakat. Dalam menjalankan tugas diperlukan monitoring oleh prinsipal pada apa yang dilakukan agen untuk mnrgurangi konflik keagenan. Kemudahan dalam mendapatkan informasi tentang pemerintah seperti publikasi laporan keuangan melalui website dapat meningkatkan pengawasan yang dilakukan oleh masyarakat kepada pemerintah.

\section{Teori Sinyal}

Evans dan Patton (1987) dalam Verawaty (2017) mengatakan dalam teori signalling pemerintah berusaha untuk memberikan sinyal yang baik kepada masyarakat. Teori sinyal menjelaskan bahwa pemerintah sebagai pihak yang diberikan amanah dari rakyat menunjukkan signal yang baik kepada masyarakat. Signal yang baik diberikan dengan cara mengungkapkan laporan keuangan yang berkualitas, jelas dan lebih detai dalam website. Laporan keuangan dijadikan sarana untuk memberikan signal kepada masyarakat karena pemerintah dapat mengemas informasi prestasi dan kinerja keuangan. Kinerja pemerintah yang baik perlu diinformasikan kepada masyarakat sebagai bentuk pertanggungjawaban.

\section{Faktor-faktor yang Mempengaruhi Transparansi, LKPD dan IFR}

Transparansi dapat diartikan sebagai kondisi dimana terdapat kemudahan dalam memperoleh informasi yang dibutuhkan baik oleh pihak dalam maupun pihak luar dari suatu institusi atau lembaga. Dalam Undang-undang No.28 tahun 1999 menyatakan bahwa transparansi adalah asas yang membuka diri terhadap hak masyarakat untuk memperoleh informasi yang benar, jujur dan tidak diskriminatif tentang penyelenggaraan negara dengan tetap memperhatikan perlindungan atas hak asasi pribadi, golongan dan rahasia negara. Transparansi dibagi menjadi dua yaitu ketersediaan informasi keuangan daerah via website dan aksesibilitas informasi keuangan daerah via website.

Ketersediaan informasi keuangan daerah via website adalah ada atau tidaknya komponen laporan keuangan daerah berdasarkan PP No.71 tahun 2010 meliputi APBD, LRA, LPSAL, Neraca, LO, LAK, LPE dan CaLK pada wesbite. Aksesibilitas adalah kemudahan oleh seseorang terhadap suatu objek, pelayanan ataupun lingkungan. Aksesibilitas dalam laporan keuangan merupakan kemudahan seseorang untuk memperoleh informasi laporan keuangan (Mulyana: 2006). Pernyataan No.1 Standar Akuntansi Pemerintahan, laporan keuangan merupakan laporan mengenai posisi keuanga dan transaksi-transaksi yang dilakukan oleh suatu entitas pelaporan. Tujuan utama adalah menyajikan informasi mengenai posisi keuangan, realisasi anggaran, arus 
kas dan kinerja keuangan suatu entitas pelaporan yang bermanfaat bagi para pengguna dalam membuat dan mengevaluasi keputusan mengenai alokasi sumber daya.

Internet financial reporting adalah suatu cara yang dilakukan perusahaan untuk mencantumkan laporan keuangannya melalui internet, yaitu melalui website perusahaan (Kusumawardani, 2011). Dengan memberikan laporan melalui internet, perusahaan mampu menyebarkan informasi secara lebih luas, lebih cepat dan murah.

Faktor-Faktor yang Mempengaruhi Transparansi Informasi Keuangan Daerah via Website Pendapatan asli daerah merupakan wujud kemandirian dalam memperoleh pendapatan sehingga dapat digunakan untuk memenuhi kebutuhan daerah dengan menggunakan mekanisme APBD. Dana alokasi umum adalah sejumlah dana yang dialokasikan pemerintah pusat kepada setiap daerah otonom (provinsi, kabupaten, kota) di Indonesia setiap tahunnya sebagai dana pembangunan. UU No. 33 tahun 2004 menyatakan Dana alokasi khusus adalah dana yang bersumber dari APBN yang dialokasikan kepada daerah tertentu dengan tujuan untuk membantu mendanai kegiatan khusus yang meruapakan urusan daerah dan sesuai dengan prioritas nasional. Rasio pembiayaan utang menunjukkan jumlah bagian aset yang dibiayai oleh utang. Rasio pembiayaan utang dilihat dari sejauh mana pemda menggunakan dana yang dupinjam untuk membiayai aset yang dimilki.

\section{Pengaruh Pendapatan Asli Daerah (PAD) terhadap Transparansi Informasi Keuangan Daerah via Website}

Pemerintah bertanggungjawab kepada masyarakat, bentuk pertanggungjawaban pemerintah adalah dengan menerbitkan laporan keuangan. Didalam laporan keuangan terdapat salah satu informasi penting yang harus diungkapkan yaitu PAD karena PAD menggambarkan kinerja pemerintah dalam satu periode. Kinerja yang tinggi merupakan sinyal dari manajemen publik yang baik. PAD merupakan wujud kemandirian dalam memperoleh pendapatan sehingga dapat digunakan untuk memenuhi kebutuhan daerah dengan menggunakan mekanisme APBD. Informasi terkait PAD harus tersedia dan dapat diakses dengan mudah oleh masyarakat. Apabila informasi terkait PAD tersedia dan dapat diakses maka pemerintahan tersebut merupakan pemerintah yang transparan hal ini didukung oleh penelitian Jeckly dan Eka (2014). Oleh karena itu dapat dirumuskan hipotesis sebagai berikut :

$\mathrm{H}_{1 \mathrm{a}}$ : Pendapatan asli daerah berpengaruh positif terhadap ketersediaan informasi keuangan daerah via website

$\mathrm{H}_{1 \mathrm{~b}}$ : Pendapatan asli daerah berpengaruh positif terhadap aksesibilitas informasi keuangan daerah via website

\section{Pengaruh Dana Alokasi Umum (DAU) terhadap Transparansi Informasi Keuangan Daerah via Website}

Dana alokasi umum adalah dana yang berasal dari APBN yang dialokasikan dengan tujuan pemerataan keuangan antar daerah untuk membiayai kebutuhan pengeluaran dalam rangka pelaksanaan desentralisasi. Informasi terkait DAU harus tersedia dan dapat diakses dengan mudah oleh masyarakat. Apabila DAU tersedia dan dapat diakses maka pemerintahan tersebut merupakan pemerintahan yang transaparan hal ini didukung oleh penelitian Liestiani (2008). Oleh karena itu dapat dirumuskan hipotesis sebagai berikut :

$\mathrm{H}_{2 \mathrm{a}}$ : Dana Alokasi Umum berpengaruh positif terhadap ketersediaan informasi keuangan daerah via website 
$\mathrm{H}_{2 \mathrm{~b}}$ : Dana Alokasi Umum berpengaruh positif terhadap aksesibilitas informasi keuangan daerah via website

\section{Pengaruh Dana Alokasi Khusus (DAK) terhadap Transparansi Informasi Keuangan Daerah via Website}

Dana alokasi khusus adalah dana yang bersumber dari APBN yang dialokasikan kepada daerah tertentu dengan tujuan untuk membantu mendanai kegiatan khusus yang merupakan urusan daerah dan sesuai dengan prioritas nasional. DAK harus tersedia dan dapat diakses. Apabila DAK tersedia dan dapat diakses maka pemerintahan tersebut transparan hal ini didukung oleh penelitian Liestiani (2009). Berdasarkan uraian diatas dapat dirumuskan hipotesis sebagai berikut :

$\mathrm{H}_{3 \mathrm{a}}$ : Dana Alokasi Khusus berpengaruh positif terhadap ketersediaan informasi keuangan daerah via website

$\mathrm{H}_{3 \mathrm{~b}}$ : Dana Alokasi Khusus berpengaruh positif terhadap aksesibilitas informasi keuangan daerah via wesbite

\section{Pengaruh Rasio Pembiayaan Utang terhadap Transparansi Informasi Keuangan Daerah via Website}

Rasio pembiayaan utang menunjukkan jumlah bagian aset yang dibiayai oleh utang. Informasi terkait rasio pembiayaan utang harus tersedia dan dapat diakses. Apabila rasio pembiayaan utang tersedia dan dapat diakses maka pemerintahan tersebut transparan hal ini didukung oleh penelitian Laswad dkk (2005). Berdasarkan uraian diatas dapat dirumuskan hipotesis sebagai berikut :

$\mathrm{H}_{4 \mathrm{a}}$ : Rasio Pembiayaan Utang berpengaruh terhadap ketersediaan informasi keuangan daerah via website

$\mathrm{H}_{4 \mathrm{~b}}$ : Rasio Pembiayaan Utang berpengaruh terhadap aksesibilitas informasi keuangan daerah via website

\section{METODE PENELITIAN}

\section{Sampel}

Penelitian ini adalah penelitian kausal komparatif. Jenis data sekunder. Data variabel independen diperoleh dari Laporan Hasil Pemeriksaan BPK tahun 2017 dan data yang diperoleh dari situs pemda yaitu 541 pemda. Data variabel dependen diperoleh dari masing-masing situs resmi pemda. Populasi penelitian adalah pemda seluruh Indonesia tahun 2007. Sampel dipilih dari populasi dengan kriteria tertentu. Penentuan sampel dalam penelitian ini adalah purposive sampling. Diperoleh jumlah sampel sebanyak 273 setelah dieliminasi oleh kriteria sampel.

\section{Teknik Analisis Data}

Teknik analisis data menggunakan dua model yaitu analisis regresi logistik dan analisis regresi berganda. Model analisis regresi logistik dalam penelitian ini adalah sebagai berikut :

$$
\mathrm{IKD}=\propto+\beta_{1} \cdot \mathrm{PAD}+\beta_{2} \cdot \mathrm{DAU}+\beta_{3} \cdot \mathrm{DAK}+\beta_{4} \cdot \mathrm{RPU}+\mathrm{e}
$$

Model analisis regresi berganda dalam penelitian ini adalah sebagai berikut :

$$
\text { IKDakses }=\propto+\beta_{1} \cdot \operatorname{PAD}+\beta_{2} \cdot \mathrm{DAU}+\beta_{3} \cdot \mathrm{DAK}+\beta_{4} \cdot \mathrm{RPU}+\mathrm{e}
$$




\section{Variabel Penelitian dan Pengukurannya}

Ketersediaan Informasi Keuangan Daerah via Website

Ketersediaan informasi keuangan daerah diukur dengan menggunakan variabel dummy, dimana untuk pemerintahan daerah yang menyediakan informasi keuangan daerah diberi skor 1, sedangkan pemerintah daerah yang tidak menyediakan informasi keuangan daerah akan diberi skor 0 .

\section{Aksesibilitas Informasi Keuangan Daerah via Website}

Aksesibilitas informasi keuangan daerah diukur dengan indeks aksesibilitas yang dikembangkan oleh Styles dan Tennyson (2007). Aksesibilitas pada penelitian ini dihitung berdasarkan ketersediaan informasi keuangan daerah pada website setiap daerah di Indonesia dan hasil penjumlahan maksimal 13 poin untuk setiap daerah.

\section{Pendapatan Asli Daerah (PAD)}

Rora (2010) menyatakan bahwa pendapatan asli daerah merupakan perbandingan besarnya pendapatan asli daerah dengan total realisasi anggaran pendapatan yang diterima. Semakin besar pendapatan asli daerah, maka semakin menunjukkan kinerja pemerintah daerah yang baik dan sebaliknya.

$$
\mathrm{PAD}=\text { Total PAD/Total Realisasi Anggaran }
$$

\section{Dana Alokasi Umum (DAU)}

Dana alokasi umum merupakan salah satu transfer dana pemerintah kepada pemerintah daerah yang bersumber dari pendapatan APBN dengan tujuan pemerataan kemampuan keuangan antar daerah.

$$
\text { Dana Alokasi Umum }=\text { Total DAU/Total Realisasi Anggaran }
$$

\section{Dana Alokasi Khusus (DAK)}

Dana alokasi khusus merupakan salah satu transfer dana pemerintah kepada daerah yang bersumber dari pendapatan APBN yang dialokasikan kepada daerah tertentu dengan tujuan untuk membantu mendanai kegiatan khusus yang merupakan urusan daerah dan sesuai dengan prioritas nasional.

$$
\text { Dana Alokasi Khusus }=\text { Total DAK/Total Realisasi Anggaran }
$$

\section{HASIL DAN PEMBAHASAN Analisis Statistik Deskriptif}

Digunakan untuk menganalisis serta mendeskripsikan data beradasarkan masing-masing variabel penelitian. Hasil analisis statistik deskriptif menjelaskan rata-rata PAD adalah 0,164, rata-rata DAU adalah 0,6151, rata-rata DAK adalah 0,1481 dan rata-rata RPU adalah 0,0162

\section{Model 1 Analisis Regresi Logistik}

\section{Uji Kelayakan Model}

\section{a. Menilai -2 Log Likehood}

Omnimbus test dilakukan untuk menilai apakah model secara keseluruhan cocok (fit) dengan data yang tersedia. Pada model ini diperoleh nilai Sig 0,057 yang menunjukkan bahwa model yang dibentuk signifikan dan cocok dengan data. 


\section{b. Koefisien Determinasi (Nagelkerke R Square)}

Koefisien daterminasi digunakan untuk mengetahui seberapa besar variabilitas variabel-variabel dependen mampu memperjelas variabilitas independen. Nilai ini dapat dilihat dari nilai Nagelkerke R Square. Nilai Nagelkerke R Square sebesar 0,047 yang berarti variabilitas dependen yang dapat dijelaskan variabel independen adalah sebesar $4,7 \%$, sedangkan sisanya 95,3\% dijelaskan oleh variabilitas variabel-variabel lain diluar model penelitian ini.

\section{c. Hosmer and Lemeshow Test}

Hosmer and Lemeshow Test digunakan untuk menilai kelayakan keseluruhan dari suatu model regresi. Nilai Chi-square 6,293 dengan nilai Sig. Sebesar 0,614, Sig lebih besar dari nilai alpha artinya tidak ada perbedaan nyata antara klasifikasi yang diprediksi dengan klasifikasi yang diamati. Hal ini berarti model regresi logistik dikatakan dapat diterima karena sesuai dengan data observasinya.

\section{Menilai Akurasi Model (Classification Table)}

Menilai akurasi model digunakan untuk melihat seberapa baik prediksi model penelitian.Menurut prediksi, pemda yang menyediakan informasi keuagan di website adalah 82 pemda, sedangkan observasi sesungguhnya menunjukkan bahwa pemda yang menyediakan informasi keuangan via website adalah sebanyak 4 pemda. Pemda yang tidak menyediakan informasi keuangan via website adalah sebanyak 191 pemda, sedangkan observasi sesungguhnya menunjukkan bahwa pemda yang tidak menyediakan informasi keuangan daerah via website sebanyak 185 pemda.

\section{Model Regresi yang Dihasilkan (Variables In the Equation)}

Variables in the equation digunakan untuk menunjukkan hasil pengujian koefisien regresi logistik atas model penelitian. Nilai B menunjukkan koefisien dari setiap variabel bebas yang diuji. Sementara nilai Exp (B) menunjukkan besarnya kemungkinan adanya ketersediaan informasi keuangan pada setiap pemda.

Tabel 1

Varaibles in the Equation

\begin{tabular}{|c|c|c|c|c|c|c|c|c|c|}
\hline \multirow{3}{*}{ 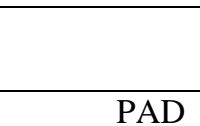 } & \multirow[t]{2}{*}{ B } & \multirow[t]{2}{*}{ S.E. } & \multirow[t]{2}{*}{ Wald } & \multirow[t]{2}{*}{$\mathrm{dF}$} & \multirow{2}{*}{\multicolumn{2}{|c|}{ Sig. }} & \multirow[t]{2}{*}{$\operatorname{Exp}(B)$} & \multicolumn{2}{|c|}{ 95\% C.I for $\operatorname{Exp}(B)$} \\
\hline & & & & & & & & Lower & Upper \\
\hline & , 160 & 1,212 & 017 & & 1 & 895 & 1,174 & , 109 & 12,622 \\
\hline DAU & $-1,466$ & 2,449 & 358 & & 1 &, 549 & ,231 & 002 & 28,046 \\
\hline Step 1 DAK & $-2,213$ & 1,352 & 2,680 & & 1 & 102 & 109 & ,008 & 1,547 \\
\hline RPU & 7,404 & 6,353 & 1,358 & & 1 & ,244 & 1641,732 & ,006 & 419870120,343 \\
\hline IKD & 208 & 800 &, 068 & & 1 & 794 & 1,232 & & \\
\hline
\end{tabular}

Sumber : Data Sekunder yang diolah, 2019

\section{Model II Analisis Regresi Berganda \\ Uji Asumsi Klasik \\ a. Uji Normalitas}

Uji normalitas bertujuan untuk menguji apakah dalam model regresi variabel memiliki distribusi normal. Hasil uji normalitas menyatakan nilai Kolmogrov-Smirnov untuk variabel aksesibilitas sebesar 4,191 dengan signifikansi ,000 dapat dinyatakan data yang digunakan dalam penelitian ini telah berdistribusi normal. 


\section{b. Uji Multikolinearitas}

Uji multikolinearitas bertujuan untuk menguji apakah dalam model regresi ditemukan adanya korelasi antar variabel bebas. Model regresi yang baik adalah tidak terjadi korelasi antar variabel bebas. Diperoleh nilai VIF untuk masing-masing variabel bebas kurang dari 10 dan tolerance value berada diatas 0,10 . Hal ini menunjukkan tidak adanya korelasi antara sesama variabel bebas dalam model regresi dan disimpulkan tidak terdapat masalah multikolinearitas antara sesama variabeb bebas.

\section{c. Uji Heteroskedastisitas}

Uji heteroskedastisitas dilakukan untuk menguji apakah dalam model regresi terjadi ketidaksamaan variance dari residual satu pengamatan ke pengamatan lain. Diketahuai bahwa nilai Sig variabel PAD sebesar 0,004, DAU sebesar 0,148, DAK sebesar 0,400 dan RPU sebesar 0,386 . Hal ini menunjukkan nilai Sig lebih kecil dari nilai alpha.

\section{Uji Kelayakan Model}

a. Uji F (Uji Signifikansi Serentak)

Uji F digunakan untuk membuktikan apakah variabel bebas secara bersama-sama mempengaruhi variabel terikat.

Tabel 2

Hasil F-Test

\begin{tabular}{llrrrrr}
\hline Model & & Sum of Square & Df & Mean Square & F & \multicolumn{1}{c}{ Sig. } \\
\hline \multirow{3}{*}{1} & Regression & 52,022 & 4 & 13,005 & 3,441 &, 009 \\
& Residual & 1012,932 & 268 & 3,780 & & \\
& Total & 1064,954 & 272 & & & \\
\hline
\end{tabular}

Sumber : Data Sekunder yang diolah, 2019

Dari hasil pengujian, diperoleh nilai F sebesar 3,441 dengan nilai Sig 0,009. Dari hasil tersebut terlihat bahwa Sig lebih kecil dari nilai alpha maka model diterima.

\section{b. Uji $\mathbf{R}^{2}$ (Koefisien Determinasi)}

Koefisien determinasi digunakan untuk mengukur seberapa besar variasi dari nilai variabel terikatnya dapat dijelaskan oleh variasi nilai dari variabel-variabel bebasnya.

\section{Tabel 3}

\begin{tabular}{|c|c|c|c|c|}
\hline \multicolumn{5}{|c|}{ Hasil Uji $\mathbf{R}^{2}$} \\
\hline Model & $\mathbf{R}$ & R Square & $\begin{array}{l}\text { Adjusted R } \\
\text { Square }\end{array}$ & $\begin{array}{l}\text { Std. Error of the } \\
\text { Estimate }\end{array}$ \\
\hline 1 & ,221 & 0,49 & 0,35 & 1,94412 \\
\hline
\end{tabular}

Pada tabel diatas menunjukkan nilai Adjusted $\mathrm{R}$ Square sebesar 0,035 yang berarti variablitas variabel dependen yang dapat dijelaskan variabel independen adalah sebesar 3,5\% sedangkan sisanya 96,5\% dijelaskan oleh variabilitas variabel-variabel lain diluar model penelitian ini. Atau secara keseluruhan variabel PAD, DAU, DAK, RPU dapat menjelaskan prediksi aksesibilitas informasi keuangan daerah via website sebesar 3,5\%. 
Tabel 4

Analisis Regresi Linear Berganda

\begin{tabular}{|c|c|c|c|c|c|c|c|c|}
\hline \multirow{2}{*}{\multicolumn{2}{|c|}{ Model }} & \multicolumn{2}{|c|}{$\begin{array}{l}\text { Unstandarized } \\
\text { Coefficients }\end{array}$} & \multirow{2}{*}{$\begin{array}{c}\begin{array}{l}\text { Standarized } \\
\text { Coefficients }\end{array} \\
\text { Beta }\end{array}$} & \multirow[t]{2}{*}{$\mathbf{t}$} & \multirow[t]{2}{*}{ Sig } & \multicolumn{2}{|c|}{ Collinearity Statistics } \\
\hline & & B & $\begin{array}{c}\text { Std. } \\
\text { Error }\end{array}$ & & & & Tolerance & VIF \\
\hline \multirow{5}{*}{1} & (Constant) & 4,143 & ,688 & & 6,019 & ,000 & & \\
\hline & PAD & 3,419 & 1,606 & ,131 & 2,128 & 034 & ,951 & 1,052 \\
\hline & DAU &,- 056 &, 077 &,- 044 &,- 726 & 468 & ,972 & 1,029 \\
\hline & DAK & -2502 & 3,660 &,- 042 &,- 684 & ,495 & ,947 & 1,056 \\
\hline & RPU & 12,138 & 9,919 &, 072 & 1,224 & ,222 & 964 & 1,037 \\
\hline
\end{tabular}

Sumber : Data Sekunder yang diolah, 2019

Pembahasan

Pengaruh Pendapatan Asli Daerah terhadap Transparansi Informasi Keuangan Daerah via Website

Pendapatan asli daerah adalah penerimaan yang diperoleh daerah dari sumber-sumber dalam wilayahnya sendiri yang dipungut berdasarkan peraturan daerah sesuai dengan peraturan perundang-undangan yang berlaku. Berdasarkan hasil olahan statistik model 1 yang telah dilakukan menyatakan bahwa hipotesis 1a ditolah. Hal ini dapat dilihat pada nilai tabel 11, koefisien regresi PAD sebesar 0,160 dan nilai signifikansi 0,895 lebih besar dari nilai alpha = 0,05 yang berarti PAD tidak berpengaruh signifikan terhadap variabel ketersediaan informasi keuangan via website. Oleh karena itu hipotesis 1a ditolak.

Selanjutnya merujuk pada hasil olahan statistik untuk model 2 tabel 17, hipotesis $1 \mathrm{~b}$ diterima. Dilihat dari nilai signifikansinya 0,034 lebih kecil dari alpha $=0,05$. Ini berarti bahwa variabel PAD secara statistik berpengaruh terhadap variabel aksesibilitas informasi keuanga daerah via website.

\section{Pengaruh Dana Alokasi Umum terhadap Transparansi Informasi Keuangan Daerah via Website \\ Hasil hipotesis pada penelitian membuktikan bahwa hipotesis 2a ditolak karena nilai Sig = 0,549 lebih besar dari alpha maka dana alokasi umum tidak berpengaruh terhadap ketersediaan informasi keuangan daerah via website. Selanjutnya hipotesis $2 \mathrm{~b}$ ditolak terlihat pada tabel 17 bahwa nilai sig $=0,468$ lebih besar dari alpha maka variabel DAU secara statistik tidak berpengaruh terhadap variabel aksesibilitas informasi keuangan daerah via website.}

\section{Pengaruh Dana Alokasi Khusus terhadap Transparansi Informasi Keuangan Daerah via Website Hasil penelitian membuktikan bahwa hipotesis 3a ditolak dapat dilihat pada tabel 11 nilai sig = 0,102 lebih besar dari alpah maka DAK tidak berpengaruh terhadap transparansi informasi keuangan daerah via website. Selanjutnya hipotesis 3b ditolak terlihat pada tabel 17 bahwa nilai sig $=0,495$ lebih besar dari alpha makan DAK tidak berpengaruh terhadap aksesibilitas informasi keuangan daerah via website.}

\section{Pengaruh Rasio Pembiayaan Utang terhadap Transparansi Informasi Keuangan Daerah via Website}

Berdasarkan hasil olahan statistik model 1 dalam penelitian ini menyatakan bahwa hipotesis 4a ditolak. Melalui pengujian regresi logistik didapatkan bahwa rasio pembiayaan 
utang tidak berpengaruh terhadap ketersediaan informasi keuangan daerah via website, dapat dilihat pada tabel 11 yang menyatakan bahwa pada variabel rasio pembiayaan utang diperoleh nilai sig $=0,244$ yang mana lebih besar alpha 0,05 .

Selanjutnya pada tabel 17 menyatakan pada variabel rasio pembiayaan utang diperoleh nilai $\operatorname{sih}=0,222$ yang mana lebih besar dari alpha, berarti varibel rasio pembiayaan utang tidak berpangaruh signifikan terhadap variabel aksesibilitas informasi keuangan daerah via website.

\section{SIMPULAN, KETERBATASAN DAN SARAN \\ Simpulan}

Berdasarkan analisis yang telah dilakukan, kesimpulan dari penelitian ini adalah :

1. Hasil pengujian model satu dengan regresi logistik menunjukkan bahwa PAD, DAU, DAK dan RPU tidak memiliki pengaruh signifikan terhadap ketersediaan informasi keuangan daerah via website.

2. Hasil pengujian model dua dengan regresi berganda menunjukkan bahwa PAD memiliki pengaruh signifikan terhadap aksesibilitasinformasi keuangan daerah via website, sedangkan DAU, DAK dan RPU tidak memiliki pengaruh signifikan terhadap aksesibilitas informasi keuangan daerah via website.

\section{Keterbatasan}

Berdasarkan kesimpulan dan hasil temuan penelitian ini, penulis menyadari bahwa hasil penelitian ini belum menghasilkan kesimpulan yang sempurna sehingga masih ada beberapa keterbatasan dalam penelitian ini diantaranya yaitu :

1. Penelitian ini hanya dilakukan dengan data tahun 2017 , hal ini meyebabkan hasil penelitian mungkin berbeda dengan tahun yang terbaru

2. Variabel independen pada penelitian ini masih rendah dalam menjelaskan pengaruhnya terhadap variabel dependen

3. Penelitian ini hanya menggunakan data sekunder yang ada pada LKPD yang diperiksa oleh BPK

\section{Saran}

Berdasarkan pembahasan dan kesimpulan yang terdapat dalam penelitian ini, maka peneliti mengajukan beberapa saran sebagai berikut :

1. Bagi Pemerintah Daerah

Diharapkan pemda lebih memperhatikan transparansi pemda dengan menyediakan dan mempermudah akses dalam memperoleh informasi keuangan di website.

2. Bagi Penelitian Selanjutnya

a. Diharapkan penelitian selanjutnya lebih memaksimalkan penelitian dengan menambah faktor-faktor lain yang diduga dapat mempengaruhi transparansi informasi keuangan daerah via website seperti sturktur pemerintahan, tingkat pendidikan masyarakat, tingkat popularitas website pemda dan kebutuhan pengguna informasi.

b. Penelitian selanjutnya juga diharapkan dapat menambah sumber data yang digunakan maupun waktu dari penelitian agar mendapatkan hasil yang lebih maksimal dan akurat. 


\section{DAFTAR PUSTAKA}

Agustin, Henri; Arza, Fefri Indra. (2019). Potrait of Accountability and Transparency in Local Budget Management by the Regional Government in West Sumatera Province, Indonesia: An Anomaly in Digital Era. $4^{\text {th }}$ Padang International Conference on Education, Economics, Business and Accounting (PICEEBA-2 2019). Padang. 154-166.

Agustin, Henri. (2014). Publikasi Dokumen Pengelolaan Anggaran pada Website Pemkab/Pemkot di Propinsi Sumatera Barat. Seminar Nasional Aplikasi Teknologi Informasi (SNATI). Yogyakarta.

A, Chariri \& Imam Ghozali. (2007). Teori Akuntansi. Semarang: Badan Penerbit Universitas Diponegoro.

Abdul, Halim. (2004). Akuntansi Keuangan Daerah. Jakarta: Salemba Empat.

Abdul, Halim. (2007). Akuntansi Sektor Publik : Akuntansi Keuangan Daerah. Jakarta : Salemba Empat.

Afryansyah, Rahmad Dian. (2013). Faktor-Faktor Yang Mempengaruhi Pengungkapan Informasi Akuntansi di Internet Oleh Pemerintah Daerah. Universitas Diponegoro. Semarang.

Ardhani, Pungky. (2011). Pengaruh Pertumbuhan ekonomi, Pendapatan Asli Daerah, Dana Alokasi Umum, dan Dana Alokasi Khusus terhadap Pengalokasian Anggaran Belanja Modal. Universitas Diponegoro. Semarang.

Arifianto, Y. (2005). Sistem Pengelolaan Anggaran Belanja Militer di Indonesia : Tinjauan Aspek Pengendalian, Transparansi dan Akuntabilitas Publik. Universitas Indonesia. Depok.

Arista, Dessy. (2015). Tranparansi Informasi Situs Web Pemerintah Daerah di Sulawesi Selatan Sebagai Implementasi Keterbukaan Informasi Publik. Universitas Hasanuddin. Makassar.

Badan Pemeriksa Keuangan Republik Indonesia. (2017). Ikhtisar Hasil Pemeriksaan Tahun 2017 Badan Pemeriksa Keuangan Republik Indonesia. Jakarta. BPK RI.

Bastian, Indra. (2006). Akuntansi Sektor Publik: Suatu Pengantar. Jakarta: Erlangga.

Christiaens, J. (1999). Financial Accounting Reform in Flemish Municipalities: An Emprical Investigation. Financial Accountability \& Management.

Craven, B., \& Marston, C. (1999). Financial reporting on the internet by leading UK ompanies. The European Accounting Review

Evan, G. T. (2003). Accounting Theory : Contemporary Accounting Issues. Australia.

Fitriasari, Debby \& Dwi Martani. (2013). Tranparansi Keuangan Dan Kinerja Pada Website Pemerintah Daerah Kebupaten/Kota di Indonesia. Universitas Indonesia. Depok.

Folscher. (2000). Transparency and Participation in The Budget Process. South Africa: A Country Report 1.

Ghozali, Imam. (2005). Aplikasi Analisis Multivariate dengan Program SPSS. Semarang: Badan Penerbit Universitas Diponegoro.

Godfrey, J., A. Hodgson, S. Holms , \& A. Tarca. (2010). Accounting Theory. Australia: John Wiley \& Sons.

Gore, A. (2004). The Effects of GAAP Resolution and Bond Market Interaction on Local Government Disclosure. Journal Accounting dan Public Policy.

Groff, J.E., \& Pittman, M.K. (2004). Municipal Financial Reporting on The World Wide Web: A Survey of Financial Data Displayed on The Official Websites of The 100 Largest U.S. Municipalities. Journal of Government Financial Management.

Gujarati, D. (2007). Dasar - Dasar Ekonometrika. New Delhi 
Hair, J. F., Black, W. C., Babin, B. J., \& Anderson, R. E. (2009). Multivariate Data Analysis. Pearson New International Edition.

Harahap, Sofyan Safri. (2002). Teori Akuntansi Laporan Keuangan. Jakarta: Bumi Aksara.

Hargyantoro, Febrian. (2010). Pengaruh Internet Financial Reporting dan Tingkat pengungkapan Informasi Website Terhadap Frekuensi Perdagangan Saham Perusahaan. Universitas Diponegoro. Semarang.

Hastuti, Arum Indri. (2015). Faktor-Faktor Yang Mempengaruhi Penerapan Transparansi Pelaporan Keuangan Daerah di Kabupaten Boyolali. Universitas Muhammadiyah Surakarta.

Hilmi, Amiruddin Zul \& Dwi Martani. (2012). Analisis Faktor-Faktor Yang Mempengaruhi Tingkat Pengungkapan Laporan Keuangan Pemerintah Provinsi. Universitas Indonesia. Depok.

Hudoyo, Yacoeb Triandy \& Amir Mahmud. (2014). Faktor-Faktor Yang Mempengaruhi Pengungkapan Laporan Keuangan di Internet oleh Pemerintah Daerah. Universitas Negeri Semarang

IASC. (1999). Business Reporting on the Internet. International Accounting Standards Committee.

Indriantoro, Nur, \& Bambang Supomo. (1999). Metodologi Penelitian dan Bisnis. Yogyakarta: BPFE Yogyakarta

Indriantoro, Nur \& Bambang Supomo. (2002). Metodologi Penelitian Bisnis Untuk Akuntansi dan Manajemen. Yogyakarta: BPFE Yogyakarta

Ingram, R. (1984). Incentives and the Choices of State Government Accounting. Journal of Accounting Research.

Instruksi Presiden Republik Indonesia No 6 Tahun 2001 Tentang Pengembangan dan Pendayagunaan Telematika di Indonesia.

Instruksi Presiden Republik Indonesia No 3 Tahun 2003 Tentang Kebijakan dan Strategi Nasional Pengembangan e-Government.

Jeckly, Dharma Jaya dan Eka Ardhani .(2014). Pengaruh Pendapatan Asli Daerah, Dana Alokasi Umum, dan Belanja Modal Pada Kelengkapan Pengungkapan Informasi Keuangan Daerah Melalui Situs Resmi Pemerintah Provinsi. Universitas Udayana. Bali

Jensen, M., \& Meckling W. (1976). Theory of the firm: managerial behavior, agency costs, and ownership structure. Journal of Financial Economics.

Keumala, Novita Nisa. (2013). Analisis Faktor-Faktor Yang Mempengaruhi Pelaporan Keuangan Perusahaan Melalui Website Perusahaan. Universitas Diponegoro. Semarang.

Kieso, Donald E., Jerry J. Weygandt, dan Terry D. Warfield. (2007). Akuntansi Intermediete. Jakarta: Penerbit Erlangga.

Krina P, Loina Lalolo. (2003). Indikator dan Alat Ukur Prinsip Akuntabilitas, Transparansi \& Partisipasi. Jakarta : Sekretariat Good Public Governance Bappenas.

Kusumawardani, Arum. (2011). Analisis faktor-faktor yang mempengaruhi pelaporan keuangan melalui internet (Internet Financial Reporting) dalam website perusahaan. Universitas Diponegoro. Semarang.

Laswad, F., Fisher, R. Oyelere, P. (2005). Determinants of Voluntary Internet Financial Reporting by Local Goverment Authorities. Journal of Accounting and Public Policy.

Liestiani, Annisa. (2008). Disclosure In Local Government Financial Statements: The Case of Indonesia. Global Review of Accounting And Financial 
Lubis, Annisa Thahirah. (2015). Faktor-Faktor Yang Mempengaruhi Tranparansi Informasi Keuangan Pada Website Resmi Pemerintah Daerah di Indonesia. Universitas Sumatera Utara. Medan.

Mardiasmo. (2009). Akuntansi Sektor Publik. Yogyakarta

Medina, Febri. (2012). Faktor-faktor yang mempengaruhi transparansi informasi keuangan pada situs resmi pemerintah daerah di Indonesia. Universitas Indonesia. Depok.

Morris, R. D. (1987). Signaling, Agency Theory and Accounting Policy Choice. Accounting and Business Research.

Mulyana, Budi. (2006). Pengaruh Penyajian Neraca Daerah dan Aksesibilitas Laporan Keuangan Terhadap Transparansi dan Akuntabilitas Pengelolaan Keuangan Daerah. Universitas Gajah Mada. Yogyakarta.

Mustofa, Anies Iqbal. (2012). Pengaruh Penyajian dan Aksesibilitas Laporan Keuangan Terhadap Akuntabilitas Pengelolaan Keuangan Kabupaten Pemalang. Universitas Negeri Semarang.

Nainggolan, Agus Tubels dan Dyah Purwanti. (2016). Analisis Faktor-faktor yang mempengaruhi transparansi informasi keuangan daerah via website. Simposium Nasional Akuntansi XIX Lampung.

Ningsih, Resti Febriya. (2018). Analisis Faktor-Faktor Yang Mempengaruhi Transparansi Informasi Keuangan Daerah via Website. Universitas Negeri Padang. Sumatera Barat.

Novia, Siswita; Arza, Fefri Indra; Agustin, Henri. (2015). Studi Kebutuhan Informasi Pengguna Laporan Keuangan Pemerintah Kota Padang (Studi Empiris pada DPRD dan SKPD Kota Padang). Jurnal WRA, 3(1), 529-548.

Peraturan Menteri Dalam Negeri Nomor 13 Tahun 2006 tentang Pedoman Pengelolaan Keuangan Daerah.

Peraturan Menteri Dalam Negeri Nomor 21 Tahun 2011 tentang Klasifikasi Belanja Daerah

Peraturan Pemerintah Republik Indonesia Nomor 56 Tahun 2005 tentang Sistem Informasi Keuangan Daerah

Peraturan Pemerintah Republik Indonesia Nomor 71 Tahun 2010 tentang Standar Akuntansi Pemerintahan

Pitri, Dian Pratiwi dan Merina. (2017). Faktor-faktor Penentu Transparansi Informasi Keuangan Daerah Melalui E-Government Pemerintah Kabupaten/Kota di Provinsi Sumatera Selatan. Universitas Bina Darma. Sumatera Selatan.

Puspita, Rora \& Dwi Martani. (2012). Analisis pengaruh kinerja dan karakteristik pemda Terhadap tingkat pengungkapan dan kualitas informasi dalam website pemda. Universitas Indonesia. Depok.

Rahmawati, Ria Aini \& Amir Mahmud. (2016). Faktor-Faktor Yang Mempengaruhi Transparansi Pelaporan Keuangan Pemerintah Daerah. Accounting Analysis Journal.

Retnowati, Endang. (2012). Keterbukaan Informasi Publik dan Good Governance (Antara Das Sein dan Das Sollen).

Rohman, Abdul. (2009). Pengaruh Penyajian Laporan Keuangan Daerah dan Aksesibilitas Laporan Keuangan Terhadap Penggunaan Informaso Keuangan Daerah. Universitas Diponegoro. Semarang.

Rora, Puspita Sari. (2010). Pengaruh Kinerja, Tingkat Ketergantungan dan Karakteristik Pemda Terhadap Tingkat Pengungkapan Sukarela pada Situs Pemda Tahun 2010. Universitas Indonesia. Depok. 
Rosita, Ladya Risqa Ayu \& Johan Arifin. (2017). Determinan Kualitas Pengungkapan Laporan Keuangan Dalam Website Pemerintah Daerah. Universitas Islam Indonesia. Yogyakarta.

Sekaran, Uma. (2006). Research Methods for Business : "Metodologi Penelitian untuk Bisnis. Jakarta : Salemba Empat

Shende, Suresh \& Tony Bennerr. (2004). Concept Paper 2: Transparency and Accountability in Public Financial Administration.

Sinaga, Yurisca Febriyanty. (2011). Analisis Faktor-Faktor Yang Mempengaruhi Pelaporan

Keuangan di Internet Secara Sukarela oleh Pemerintah Daerah. Universitas Diponegoro. Semarang.

Sumarjo, Hendro. (2010). Pengaruh Karakteristik Pemerintah Daerah Terhadap Kinerja Keuangan Pemerintah Daerah Studi Empiris Pada Pemerintah Daerah Kabupaten/Kota Di Indonesia. Universitas Sebelas Maret. Surakarta.

Suwardjono. (2005). Teori Akuntansi. Perekayasaan Pelaporan Kauangan. Yogyakarta.

Styles, A.K., \& Tennyson, M. (2007). The accessibility of financial reporting of u.s municipalities on the internet. Journal of Public Budgeting, Accounting \& Financial Management.

Syafitri. (2009). Pengaruh Pertumbuhan Ekonomi, Pendapatan Asli Daerah, Dana Alokasi Umum terhadap Pengalokasian Anggaran Belanja Modal pada Pemerintah Kabupaten/Kota di Provinsi Sumatera Utara. Universitas Sumatera Utara. Medan.

Syafitri, Febriyani. (2012). Analisis Pengaruh Karakteristik Pemerintah Daerah terhadap Tingkat Pengungkapan Laporan Keuangan. Universitas Indonesia. Depok.

Trisnawati, M. D., Achmad, K. (2014). Determinan Publikasi Laporan Keuangan Pemerintah Daerah Melalui Internet. Simposiun Nasional Akuntansi (SNA) 17 Mataram. Universitas Brwijaya. Malang

Undang-undang Republik Indonesia No. 28 Tahun 1999 tentang Penyelenggaraan Negara yang bebas KKN

Undang-Undang Republik Indonesia No 32 Tahun 2004 tentang Pemerintah Daerah

Undang-undang Republik Indonesia No. 33 Tahun 2004 tentang Perimbangan Keuangan antara Pemerintah Pusat dan Pemerintahan Daerah.

Undang-undang Republik Indonesia No. 14 Tahun 2008 tentang Keterbukaan Informasi Publik

Undang-undang Republik Indonesia No. 71 Tahun 2010 tentang Standar Akuntansi Pemerintahan Berbasis Akrual.

Verawaty. (2017). Determinan Transparansi Informasi Keuangan Daerah Melalui EGovernment Pemerintah Daerah Di Sumatera Selatan. Universitas Bina Darma. Sumatera Selatan.

Yurisca, Febriyanty Sinaga \& Tri Jatmiko. (2011). Analisis Faktor-Faktor yang Mempengaruhi Pelaporan Keuangan di Internet Secara Sukarela oleh Pemerintah Daerah.Universitas Diponegoro. Semarang.

Zimmerman, Jerold L. (1977). The Municipal Accounting Maze: An Analysis of Political Incentives. Journal of Accounting Research. 